\title{
Analysis The Role Of Correctional Center (Bapas) The Exemption Conditional
}

\section{Timbul Mangaratua Simbolon ${ }^{1}$}

\begin{abstract}
The problems of this study are 1) What is the role BAPAS of prisoners who have gained parole? 2) Any constraints faced by BAPAS in conducting guidance to inmates who obtain parole? The method used in this study using qualitative analysis, that takes into account the facts that exist in the field of practice which are then compared with the description obtained from the study of literature. From this analysis it can be seen the effectiveness of the criminal system that is instructive to the child as a criminal. Data obtained from both primary data and secondary data then analyzed qualitative diskritif troubleshooting procedures examined by exposing data have been obtained from the library studies and field studies were analyzed with the form of conclusions. The results using this sociological juridical methods conclude that: 1) Implementation guidance is felt still far from the expectations of the client, because the guidance conducted by the social counselor counsels are only just so monotonous at all. Whereas in the implementation of the Directive No. E-39-PR.05.03 of 1987 regarding Correctional Client Guidance was mentioned about the forms of activity, so that what has been a guide in the implementation of forms of activity can not run properly, 2).Constraints can be divided into two factors, namely the constraints caused by internal factors and constraints caused by external factors. As the constraints caused by the internal factor is the perception that the client to obtain a conditional release will apply to both the public, As for the problems caused by external factors is the client's premises much an obstacle for the client to do a report that it was his duty, so sometimes it is supervising the relevant social grant a dispensation for the client to do the report at a certain time.

Keywords: Strategy; Correctional Centers (BAPAS) Non-Conditional.
\end{abstract}

\section{Introduction}

Correctional Centers (BAPAS) is an institution very active role in the development of behavior as an inmate given a function by which the agency participated in an inmate's poise parole are decided by the minister of justice.

Implementation of rights of prisoners stipulated in the Act No. 12 of 1995 on the Penal and it is based on Government Regulation No. 32 of 1999 on the Terms and Procedures for Citizens Rights Patronage of Corrections. Government Regulation No. 28 of 2006 regarding Amendment to Government Regulation No. 32 of 1999 on the Terms and Procedures for Correctional Patronage Citizen Rights (hereinafter referred to Regulation No. 28 of 2006) as well as the regulation of the minister of Justice and Human Rights of the Republic of Indonesia No.M.01.04-10 of 2007 on the Terms and Procedures for Assimilation Parole.

"Criminal law until recently seen as a final remedy (ultimum remedium) given to a prisoner $1 " 2$, This statement seemed to provide an overview to us that there is no effort other than criminal sanctions in the form that serves to punish someone, on the other hand clearly criminal law contains elements that are physical punishment and imposed on a person who is guilty or against the law. The sanctions provided in the criminal law is identical to

\footnotetext{
${ }^{1}$ Student Masters (S-2) of Law Faculty of Law UNISSULA email mangarasimbolon777@gmail.com

${ }^{2}$ Sudarto Hukum Pidana I Semarang Yayasan Sudarto p.13
} 
the model of punishment which is the deprivation of personal freedom (jail) with all things contained in them which would have a tendency to wear ordeal physically against the convict, and unconsciously anyway with a model of punishment by deprivation of the will have an impact on the mental psyche of a convict.

Based on these assumptions above will arise questions that can be taken into consideration that, if there is no 'cure' other potent than 'cure' that contain criminal elements to cure 'prisoners' is? or in outline to say whether it is true criminal sanctions should be 'door' past when someone has done something illegal and guilty? In addition to the notion of 'last attempt' is still there are other reasons that would make the system or pattern of criminal old is still likely to persist and is due to the existence of a perception and old patterns still assume that sentencing is a "process of punishment" against someone, by providing severe sanctions include the imposition of suffering or sorrow in return (reward) on tort convict ". The term word "reward" in this criminalization is clear when we look at it, that impressed as a venue retaliatory negative tendency which implied the act of "revenge", as an element of vengeance in this sentencing inevitably have occurred. ${ }^{3}$

From this background, this paper is intended to analyze the implementation of BAPAS role in the parole. In this paper, the author wants to limit the issues to be observated namely concerning the role of Institute of Corrections (BAPAS) in conducting guidance to the Client Correctional obtaining parole where previously BAPAS have to exercise Society Observation (Litmas) for inmates in the face by BAPAS in conducting guidance to Correctional clients who obtain parole.

Based on this fact above need to be researched on "The Role Analysis Correctional Centers (BAPAS) in Parole."

Based on the description he ate a bag can be formulated problems in this study are: What is the role BAPAS of prisoners who have gained parole ?; Any constraints faced by BAPAS in conducting guidance to inmates who obtain parole?

\section{Results And Discussion}

\subsection{The Role of the Correctional Centers (BAPAS) Prisoners Against The Earned Parole.}

Parole is one of the coaching process for an inmate outside the institution of Corrections was viewed as a continuation of the implementation of coaching in institutions are not compromising the essence of the imposition of punishment itself, where parole is intended as a recovery against yourself inmates to life in the middle society and the family and criminal charged against the inmate was still attached, only the difference is when the inmate was still attached, only distinguishing conditional then inmates had obtained parole the convict has obtained conditional release the prisoners are free wherever he likes because it is not located within the confines of bars.Coaching parole inmates to obtain an attempt to make them as complete human beings and can be received by the family and community where inmates and live.

Related to the process for an inmate who proposed weeks to obtain parole, then BAPAS Class I Semarang as the institutional part of the correctional that will have a role to perform guidance of prisoners who have obtained the parole also has the authority to conduct Research Society as it explicitly are included in the Ministry of Justice No. JS 4/12/20 dated December 29, 1976 on the further task of BISPA converted into BAPAS also have a role to

\footnotetext{
${ }^{3}$ Op.cit Sudarto p.14.
} 
carry out the registration of the Learners Corrections and the prisoners as well as to implement the Community Guidance.

\subsection{Obstacles Faced by Correctional Centers In Doing Guidance The Clients of Corrections That Earned Parole.}

In the implementation of the guidance process under the authority of BAPAS through Community Supervisor can not be separated from the constraints that sometimes hinder the process of implementation. As for the obstacles that sometimes a barrier is ${ }^{4}$ :

- The assumption that the client to obtain a conditional release will apply to both societies.

- Technical administration that has not run in this case periodic reporting on each result of guidance.

- Transportation or insufficient official vehicles for mobility execution of tasks.

- The number of clients with social counselors that are not comparable.

Constraints mentioned above is a constraint that comes from internal factors as obstacles that sometimes having some effect on the performance of Class I BAPAS Semarang in conducting guidance to the client.

Besides the constraints derived from the above internal factors in carrying out its role, there are also external constraints are greatest effect on the implementation of the guidance to the client. These constraints include: 1) The client stay away; 2) Time and bustle clients.

Constraints are the obstacles come from internal factors ${ }^{5}:$ 1) The assumption that the client to obtain a conditional release will apply to both societies; 2) Technical administration that has not run in this case periodic reporting on each result of guidance; 3) Transportation or service vehicles which are insufficient for the task execution mobility; 4) The number of clients by social mentors are not comparable.

Constraints that occur due to external factors: 1) The client stay away ; 2) Time and bustle client

Besides the factor of residence distant clients, also from the results of the study found an obstacle in the implementation of the guidance is the time and bussiness clients. Time and bustle client is basically the daytime they work, so that in the implementation of the guidance was to be done either to report or be a visit from social supervising officer can not be implemented ${ }^{6}$.

\section{Closing}

\subsection{Conclusion}

- The second way that is done is of a social counselor BAPAS Class I Semarang conduct guidance by road to visit the client's premises, while the implementation is done within a period of 3-4 months. But in fact for the implementation of the visit is still less than the maximum time and the bustle of the client so that during the visit can not be found.

- In the implementation of the guidance which the client is guided in the midst of society

\footnotetext{
${ }^{4}$ Soekanto Soerjono. Pengantar Penulisan Hukum UI Press Jakarta 1997 p.16

${ }^{5}$ Ibid.

${ }^{6}$ Soerjono Soekanto dan Sri Mamudji. Penelitian Hukum Normatif suatu Tinjauan Singkat Raja Grafindo Persada 2001 p.67
} 
that strived to do that guidance can provide clients asking the road approaching the destination. In the implementation of such guidance is not as easy from what we imagine, in implementing the guidance certainly many constraints that barrier.

- As these constraints can be divided into two factors, namely the constraints caused by internal factors and constraints caused by external factors. As the constraints caused by the internal factor is the perception that the client to obtain a conditional release will apply to both the public perception that the client to obtain a conditional release will apply to both the community will result in poor control of the supervising social factors against the client. Technical administration that has not run in this case periodic reporting on each result of guidance so that the administration in the case of periodic reports on each result of guidance is only manifested in a report in the paper result of guidance, but should be able to be done by reporting on relevant agencies, namely Penitentiary through Head of BAPAS, Director of Corrections or those involved in the TPP (Society observer team), transport or official vehicles were not sufficient for the implementation of mobility tasks. Means to be a factor supporting the implementation of the tasks BAPAS Class I Semarang through social counselors,,

\subsection{Suggestion}

- Prior to the change point of view to assume that clients with parole is always applicable in the community, so sometimes assuming such a community supervisor considers easy, light and sometimes with what is. In this case the need becomes imperative to realize the notion that supervision is still needed so as not merely wait for clients arrested by the new authorities supervising community knows but it would be nice if more proactive social counselors.

- That as an institution that was instrumental in guiding, and providing clients life provision in the midst of society, should BAPAS Class I Semarang have guidance programs is to guide, nurture, train and give the control or supervision functions which can be integrated though simple, for example by providing skills training, workshops and seminars to broaden the client.

- Class I supposed BAPAS Semarang as an institution can perform both administrative technical administrative regulations relating to archives, archives and archival decisions relating to Class I BAPAS role of Semarang in making records and reports relating to undertake coaching role.

- Supposed to be a more effective way to do is by the clerk guidance counselors societal down to the field to meet with clients so that with the road as it can be an overview of activities, behaviors and responses of prisoners in particular and society as a social interaction.

\section{References}

[1] Soekanto, Soerjono. Pengantar Penulisan Hukum, UI Press, Jakarta, 1997

[2] Soerjono Soekanto dan Sri Mamudji. Penelitian Hukum Normatif suatu Tinjauan Singkat, Raja Grafindo Persada, 2001

[3] Sudarto. Hukum Pidana I, Yayasan Sudarto, Semarang, 1990

[4] ActNo. 23 of 2002 on Child Protection

[5] Act No. 3 of 1997 on Juvenile Justice 